\title{
Gastropods in the Intertidal Zone of Asry Beach, Kingdom of Bahrain
}

\author{
Belen T. Lumeran \\ Faculty, Science Department, AMA International University-Bahrain
}

\begin{abstract}
A study of intertidal gastropods using quadrat method was conducted from August 2012 to July 2013. Specifically to identify and classify taxonomically the gastropods in Asry Beach, Kingdom of Bahrain; find out significant differences in the number of identified gastropods within the taxonomic groups; and determine heterogeneity and alpha diversity of species using Shannon diversity index $(\mathrm{H})$, and species richness using Magalef's (d) diversity index. A total of 2,136 individual species were identified in the sandy and rocky intertidal zones which belong to 16 families, 5 genera and 28 species of gastropods. Statistical analysis using Analysis of Variance (ANOVA) with multiple comparisons depicted significant difference on the number of gastropods at varying taxonomic groups. Result of Shannon (H) and Magalef's (d) diversity indices revealed diversity and species richness of the three species, Calliostoma selectum, Lirobittium attenuatum, and Homalopoma luridum. Gastropods are abundant in the sandy and rocky intertidal zone.
\end{abstract}

Keywords: Gastropods, Intertidal zone, Quadrat method, Magalef's diversity index.

\section{INTRODUCTION}

The small parcel of the intertidal pool is a good habitat for many life forms. The sustenance of life relies on the interdependent dynamics that begins in the intertidal zone of any marine ecosystem. Life in the intertidal zone is influenced by the interplay of abiotic cycles. Diversity indices provide the total composition of community structure which can be assessed in many ways. Alpha diversity as a method determines ecosystem stability, thus allowing the ecosystem to better withstand natural or anthropogenic disturbances. The Shannon diversity index (H) describes alpha diversity in a community. Species richness can be described with Margalef's index which will provide data on community index. Marine organisms differ conspicuously according to their means of dispersion. The organisms that inhabit the shorelines are found to be zoned according to the type of immersion in sea water that they require for survival [1]. The gastropods seem to be the abundant animals in the intertidal pool since these organisms are remarkably diverse [2]. The type of substrate also determines the type of organism [3]. Studies on the pattern of distribution and diversity of gastropods were conducted in various marine ecosystems [4-8]. Characteristically, gastropods have worldwide distribution considering their wide adaptations [9].

Bahrain is strategically located in the Gulf region characterized by sprawling marine ecosystems. One of the public beaches of interest is Asry in Al Muharraq, a shipyard and docking station other than the presence of industrial plant and human habitation. In the north-eastern part is the intertidal zone characterized by sandy and rocky substrates. This area is used for recreation and a public beach resort where the study was conducted. Hence, this study was conducted to determine the gastropods in the intertidal zone in Asry Beach, Kingdom of Bahrain. Specifically, to identify and classify taxonomically the gastropods; find out significant differences in the number of gastropods within the taxonomic groups; and determine
Heterogeneity and alpha diversity of species using diversity index $(\mathrm{H})$, and species richness using Magalef's diversity index (d).

\section{RESEARCH METHOD}

This study made use of a descriptive-experimental research design. A $50 \mathrm{~m}$ belt transect was established parallel to the shoreline divided into $1 \mathrm{x} 1 \mathrm{~m}^{2}$ quadrats.

\section{A. Diversity Indices and Statistical Analysis}

The distribution of gastropods occupying the same area utilizing similar resources was determined. Alpha diversity was calculated using Shannon diversity index $[\mathrm{H}]$ to find out the heterogeneity of gastropods in the area. The formula is

$$
\left.\mathrm{H}=\sum-\underset{1-1}{(\mathrm{Pi}} \text { *In } \mathrm{Pi}\right),
$$

where, $\mathrm{H}$, the Shannon diversity index; $\mathrm{Pi}$ is the fraction of the entire population made up of species $1 ; \mathrm{s}$, the number of species encountered; $\sum$, the sum from species $1 \ldots$, and In, the natural logarithm of a number. The higher the computed $\mathrm{H}$ value the more heterogeneous, hence, the more diverse the community. The $\mathrm{H}$ value also determines how the species is distributed in relation to all other species in the community. Species richness was determined using Margalef's diversity index (d) with the formula given as

$$
\mathrm{d}=\frac{S-1}{\operatorname{In} N},
$$

where $\mathrm{d}$ is the species richness index; $\mathrm{S}$, the number of species in a population, and $\mathrm{N}$, the total number of individuals in $\mathrm{S}$ species. As a measure of species diversity, the higher the index, the more diverse the organisms are. Analysis of Variance (ANOVA) with multiple comparisons was used to find out significant differences in the number of gastropods at varying taxonomic groups. 
International Advanced Research Journal in Science, Engineering and Technology

Vol. 2, Issue 7, July 2015

\section{III.RESULTS AND DISCUSSION}

A. Identified Gastropods and their Taxonomic Classification

Table 1. Identified Gastropods and their Classification Asry Beach, Kingdom of Bahrain August 2012 - July 2013

\begin{tabular}{|c|c|c|c|}
\hline \multicolumn{4}{|c|}{ Taxonomic Group } \\
\hline Family & Genus & Species & (Total) \\
\hline Batillariidae & Batillaria & attramentaria & Sowerby, 1855(3) \\
\hline Borsoniidae & Ophiodermelta & cacellata & Carpenter, 1864 (1) \\
\hline Buccidae & $\begin{array}{l}\text { Lirabuccinum } \\
\text { Volutarpa }\end{array}$ & $\begin{array}{l}\text { odirum } \\
\text { ampullarca }\end{array}$ & $\begin{array}{l}\text { Reeve, } \\
1846(10) \\
\text { Middendroft,1848 (5) }\end{array}$ \\
\hline Calliostomatidae & $\begin{array}{l}\text { Calliostoma } \\
\text { Calliostoma }\end{array}$ & $\begin{array}{l}\text { selectum } \\
\text { variegatum }\end{array}$ & $\begin{array}{l}\text { Dillwyn, } 1817(1,522) \\
\text { Carpenter, } 1864 \text { (56) }\end{array}$ \\
\hline Cerethiopsidae & Cerithiospis & sp. 1 & $(26)$ \\
\hline Cerethiidae & $\begin{array}{l}\text { Lirobittium } \\
\text { Stylidium } \\
\text { Bittium } \\
\end{array}$ & $\begin{array}{l}\text { attenuatum } \\
\text { eschrichtii } \\
\text { vanconverense }\end{array}$ & $\begin{array}{l}\text { Carpenter, } 1864(174) \\
\text { Middendroft,1848 (11) } \\
\text { Dall \& Bartsch, } 1910(5)\end{array}$ \\
\hline Collumbilidae & Astyris & aurantiaca & Dall, 1871(1) \\
\hline Epitoniidae & Opalia & borealis & Kepe, 1881(15) \\
\hline Margeliidae & $\begin{array}{l}\text { Oepota } \\
\text { Oenopota }\end{array}$ & $\begin{array}{l}\text { olivedensis } \\
\text { tabulata }\end{array}$ & $\begin{array}{l}\text { Carpenter,1864(2) } \\
\text { Carpenter, } 1864 \text { (11) }\end{array}$ \\
\hline Muricidae & $\begin{array}{l}\text { Ocinebra } \\
\text { Octinebrina } \\
\text { Nucella } \\
\text { Scabrotrophon }\end{array}$ & $\begin{array}{l}\text { inornata } \\
\text { atropupurea } \\
\text { olamellanosa } \\
\text { maltzani } \\
\end{array}$ & $\begin{array}{l}\text { Recluz, 1851(2) } \\
\text { Carpenter, 1864(3) } \\
\text { Gmelin, 1791(3) } \\
\text { Kobett \& Kuster, 1878(1) }\end{array}$ \\
\hline Olivellidae & $\begin{array}{l}\text { Callianax } \\
\text { Callianax } \\
\text { Callianax }\end{array}$ & $\begin{array}{l}\text { obiplicata } \\
\text { baetica } \\
\text { pycna }\end{array}$ & $\begin{array}{l}\text { Sowerby, } 1825(6) \\
\text { Carpenter, 1864(6) } \\
\text { S.S. Bery,1835 (4) }\end{array}$ \\
\hline Pyramidellidae & $\begin{array}{l}\text { Turbonilla } \\
\text { Turbonilla } \\
\text { Evalea } \\
\end{array}$ & $\begin{array}{l}\text { sp. } 1 \\
\text { sp. } 2 \\
\text { tenuisculpta }\end{array}$ & $\begin{array}{l}(50) \\
(6) \\
\text { Carpenter, 1864(32) } \\
\end{array}$ \\
\hline Trochidae & $\begin{array}{l}\text { Lirularia } \\
\text { Lirularia } \\
\end{array}$ & $\begin{array}{l}\text { olirulata } \\
\text { succinata }\end{array}$ & $\begin{array}{l}\text { Carpenter, 1864(56) } \\
\text { Carpenter, 1864(5) }\end{array}$ \\
\hline Turbinidae & $\begin{array}{l}\text { Homalopoma } \\
\text { Homalopoma }\end{array}$ & $\begin{array}{l}\text { luridum } \\
\text { baculum }\end{array}$ & $\begin{array}{l}\text { Dall, 1885(75) } \\
\text { Carpenter, 1864(30) }\end{array}$ \\
\hline Velutinidae & $\begin{array}{l}\text { Velutina } \\
\text { Marsenia }\end{array}$ & $\begin{array}{l}\text { velutina } \\
\text { thrombica }\end{array}$ & $\begin{array}{l}\text { O.F. Muller, 1776(3) } \\
\text { Dall, 1871(8) }\end{array}$ \\
\hline Volutidae & Arctomelon & tearns & Dall, 1871(4) \\
\hline Total: 16 & 25 & 28 & 2,136 \\
\hline
\end{tabular}

Table 1 presents the identified gastropods in the intertidal All members of the species respond similarly to changes in zone of Asry Beach, Kingdom of Bahrain, August 2012- Environmental conditions irrespective of the population July 2013. A total of 2,136 species which belong to 16 [12].

families, 25 genera, and 28 species were identified in the The different species of gastropods are usually found in sandy and rocky intertidal pool. Although the study area is a beach, results revealed the presence of gastropods in the intertidal zone. Of the 16 families, Family Muricidae comprised the most number of genera with four sepcies, followed by Family Cerethiidae and Family Olivelidae and Pyramidelidae with three species each.

Result implies that the area can still support these life forms in spite of the man-made disturbances. Gastropods are usually associated with sandy and rocky beaches [10]. The abundance and distribution of gastropods are influenced by the physical environment [11]. the costal and marine ecosystem [13] specifically in the intertidal pool [3]. The level of sea water affects the activity of the marine organisms [14]. Hence, more organisms were found in the area. This can be attributed to the adaptation of this group of animals to their habitat [34]. The diversity of gastropods is also influenced by the number of types of sub-habitats and their interaction with the environment [15].

Results of statistical analysis using ANOVA with multiple comparisons on the number of gastropods at varying taxonomic groups are presented in Table 2. 
International Advanced Research Journal in Science, Engineering and Technology Vol. 2, Issue 7, July 2015

Table 2. Results of Statistical Analysis using ANOVA with Multiple Comparison on the Number of Gastropods at Varying Taxonomic Groups

\begin{tabular}{|cccccc|}
\hline ANOVA & SS & df & MS & F & Sig. \\
\hline Between & & & & & \\
Groups & & & & & \\
115836.3 & 4 & 28959.0 & & & \\
04 & & 76 & & & \\
Within & & & 22.946 & .000 & Significa \\
Groups & & & & $*$ & nt \\
42909.82 & 34 & 162.038 & & & \\
6 & & & & & \\
Total & & & & & \\
\hline 158745.5 & 38 & & & & \\
90 & & & & & \\
\hline
\end{tabular}

*The mean difference is significant at the .05 level

As shown in table, there is a significant difference on the number of gastropods at varying taxonomic groups at .05 level.

Table 2a. Results of Multiple Comparisons at varying Taxonomic Groups

\begin{tabular}{|llll|}
\hline \multicolumn{1}{|c}{ (I) Species } & \multicolumn{1}{c}{$\begin{array}{c}(\mathrm{J}) \\
\text { Species }\end{array}$} & $\begin{array}{c}\text { Mean } \\
\text { Difference } \\
(\mathrm{I}-\mathrm{J})\end{array}$ & \multicolumn{1}{c|}{ Sig. } \\
\hline $\begin{array}{l}\text { C. selectum } \\
\text { C. }\end{array}$ & 118.8333 & $.000^{*}$ & $\begin{array}{l}\text { Significa } \\
\mathrm{nt}\end{array}$ \\
$\begin{array}{l}\text { variegatum } \\
\text { L.attenuatum } \\
\text { L.olirulata }\end{array}$ & 119.6905 & & \\
$\begin{array}{l}\text { L. attenuatum } \\
\text { C. selectum }\end{array}$ & - & & \\
$\begin{array}{l}\text { L. olirulata } \\
\text { C. selectum }\end{array}$ & -117.500 & $.000^{*}$ & $\begin{array}{l}\text { Significa } \\
\text { nt }\end{array}$ \\
\hline
\end{tabular}

Hence, a significant difference is observed in the number of the two species of Calliostoma, C. selectum $(1,522)$ and C. variegatum (56) between L. attenuatum (174) and C. variegatum (56); L. attenuatum (174) and one species of , L. olitulata (56); L. attenuatum (174) and C. selectum (1,522); and L. olirulata (56) and C. selectum (1,522). These species comprised the most number in terms of individual count (Table 2a). The organisms share the same environment that is measured as the number of species within the given area [16]. Marine environment provides a wide range of physical condition that organisms have become highly adapted [17] which are characterized by extraordinary diversification of habitats [2].

\section{B. Results of Diversity Indices}

The heterogeneity of the sampled population of gastropods as a measure of alpha diversity was determined using Shannon diversity index (H) (Table 3). Results showed that C. selectum of Family Calliostomatidae incurred the highest $\mathrm{H}$ value, 2.883, followed by $\mathrm{L}$. Attenuatum of
Table 3. Result of Shannon Diversity Index $(\mathrm{H})$ for Heterogeneity and Alpha Diversity

\begin{tabular}{|c|c|c|c|}
\hline \multicolumn{4}{|c|}{ Taxonomic Group } \\
\hline Family & Genus & Species & $\mathrm{H}$ \\
\hline Batillariidae & Batillaria & $\begin{array}{l}\text { attramentar } \\
\text { ia }\end{array}$ & 0.053 \\
\hline Borsoniidae & $\begin{array}{l}\text { Ophioderme } \\
\text { lta }\end{array}$ & cacellata & 0.08 \\
\hline Buccidae & $\begin{array}{l}\text { Lirabuccinu } \\
\text { m } \\
\text { Volutarpa }\end{array}$ & $\begin{array}{l}\text { odirum } \\
\text { ampullarca }\end{array}$ & $\begin{array}{l}0.08 \\
0\end{array}$ \\
\hline Calliostomati & Calliostoma & selectum & 2.883 \\
\hline dae & Calliostoma & variegatum & 0.854 \\
\hline $\begin{array}{l}\text { Cerethiopsida } \\
\text { e }\end{array}$ & Cerithiospis & sp. 1 & 0.308 \\
\hline Cerethiidae & Lirobittium & attenuatum & 2.12 \\
\hline & Stylidium & eschrichtii & 0.23 \\
\hline & Bittium & $\begin{array}{l}\text { vanconvere } \\
\text { nse }\end{array}$ & 0.177 \\
\hline $\begin{array}{l}\text { Collumbilida } \\
\text { e }\end{array}$ & Astyris & aurantiaca & 0 \\
\hline Epitoniidae & Opalia & borealis & 0.186 \\
\hline Margeliidae & Oepota & olivedensis & 0.046 \\
\hline & Oenopota & tabulata & 0 \\
\hline Muricidae & Ocinebra & inornata & 0.046 \\
\hline & Octinebrina & atropupure & 0.046 \\
\hline & Nucella & a & 0.046 \\
\hline & Scabrotroph & olamellano & 0 \\
\hline & on & $\begin{array}{l}\text { sa } \\
\text { maltzani }\end{array}$ & \\
\hline Olivellidae & Callianax & obiplicata & 0.124 \\
\hline & Callianax & baetica & 0.046 \\
\hline & Callianax & pycna & 0 \\
\hline Pyramidellida & Turbonilla & sp. 1 & 0 \\
\hline $\mathrm{e}$ & Turbonilla & sp. 2 & 0.778 \\
\hline & Evalea & $\begin{array}{l}\text { tenuisculpt } \\
\text { a }\end{array}$ & 0.149 \\
\hline Trochidae & Lirularia & olirulata & 0.319 \\
\hline & Lirularia & succinata & 0.186 \\
\hline Turbinidae & Homalopom & luridum & 1.00 \\
\hline & $\begin{array}{l}\text { a } \\
\text { Homalopom } \\
\text { a }\end{array}$ & baculum & 0.08 \\
\hline Velutinidae & Velutina & velutina & 0.399 \\
\hline & Marsenia & thrombica & 0.046 \\
\hline Volutidae & Arctomelon & tearns & 0.23 \\
\hline
\end{tabular}

family Certiidae, $\mathrm{H}=2.12$, and $\mathrm{H}$. luridum, $\mathrm{H}=1.00$ of Family Turbinidae. Similarly, the same species had the highest individual count (Table 1). Statistically, there is a significant difference in number of these species within the taxonomic group (Table 2). Results imply that the identified species are more diverse compared to other species. These species are frequently occurring in the sampled quadrats. Species have specific adaptations [12] regardless of geographic distribution [2]. The coastal components are the most biologically diverse of all the marine ecosystems [10]. The use of mathematical indices evaluates the status of a particular ecosystem [18]. 
International Advanced Research Journal in Science, Engineering and Technology Vol. 2, Issue 7, July 2015

Table 4. Result of Margalef's Diversity Index (d) for Species Richness

\begin{tabular}{|c|c|c|c|}
\hline \multicolumn{4}{|c|}{ Taxonomic Group } \\
\hline Family & Genus & Species & $\mathrm{d}$ \\
\hline Batillariidae & Batillaria & $\begin{array}{l}\text { attramentar } \\
\text { ia }\end{array}$ & 0 \\
\hline Borsoniidae & $\begin{array}{l}\text { Ophioderme } \\
\text { lta }\end{array}$ & cacellata & 0 \\
\hline Buccidae & $\begin{array}{l}\text { Lirabuccinu } \\
\mathrm{m} \\
\text { Volutarpa }\end{array}$ & $\begin{array}{l}\text { odirum } \\
\text { ampullarca }\end{array}$ & $\begin{array}{l}3.2 \\
1.6\end{array}$ \\
\hline \multirow{2}{*}{$\begin{array}{l}\text { Calliostomati } \\
\text { dae }\end{array}$} & Calliostoma & selectum & 56.51 \\
\hline & Calliostoma & variegatum & 13.19 \\
\hline $\begin{array}{l}\text { Cerethiopsida } \\
\text { e }\end{array}$ & Cerithiospis & sp. 1 & 0 \\
\hline \multirow[t]{3}{*}{ Cerethiidae } & Lirobittium & attenuatum & 51.8 \\
\hline & Stylidium & eschrichtii & 4.79 \\
\hline & Bittium & $\begin{array}{l}\text { vanconvere } \\
\text { nse }\end{array}$ & 1.38 \\
\hline $\begin{array}{l}\text { Collumbilida } \\
\mathrm{e}\end{array}$ & Astyris & aurantiaca & 0 \\
\hline Epitoniidae & Opalia & borealis & 0 \\
\hline \multirow[t]{2}{*}{ Margeliidae } & Oepota & olivedensis & 0.69 \\
\hline & Oenopota & tabulata & 3.57 \\
\hline \multirow[t]{5}{*}{ Muricidae } & Ocinebra & inornata & 2.07 \\
\hline & Octinebrina & atropupure & 3.29 \\
\hline & Nucella & $\mathrm{a}$ & 3.29 \\
\hline & Scabrotroph & olamellano & 0 \\
\hline & on & $\begin{array}{l}\text { sa } \\
\text { maltzani }\end{array}$ & \\
\hline \multirow[t]{3}{*}{ Olivellidae } & Callianax & obiplicata & 4.394 \\
\hline & Callianax & baetica & 5.46 \\
\hline & Callianax & pycna & 2.77 \\
\hline \multirow{3}{*}{$\begin{array}{l}\text { Pyramidellida } \\
\text { e }\end{array}$} & Turbonilla & sp. 1 & 20.8 \\
\hline & Turbonilla & sp. 2 & 3.58 \\
\hline & Evalea & $\begin{array}{l}\text { tenuisculpt } \\
\text { a }\end{array}$ & 13.97 \\
\hline \multirow[t]{2}{*}{ Trochidae } & Lirularia & olirulata & 12.727 \\
\hline & Lirularia & succinata & 1.61 \\
\hline \multirow[t]{2}{*}{ Turbinidae } & Homalopom & luridum & 31.94 \\
\hline & $\begin{array}{l}\text { a } \\
\text { Homalopom }\end{array}$ & baculum & 5.42 \\
\hline \multirow[t]{2}{*}{ Velutinidae } & Velutina & velutina & 1.09 \\
\hline & Marsenia & thrombica & 4.63 \\
\hline Volutidae & Arctomelon & tearns & 0 \\
\hline
\end{tabular}

Results in Table 5 showed that C. selectum of Family Calliostomatidae had the highest (d) index, 56.51, followed by L. attenuatum (Family Cerithiidae), $d=51.8$, and H. luridum (Family Turbinidae), $d=31$. These three species are also the most diverse as shown in the result of Shannon diversity index $(\mathrm{H})$ (Table 3 ). Species population has its own dynamics based on abundance [19]. Marine gastropods have high diversity [20] since this group contains a vast number of named species [2]. Hence, it can be implied that Asry Beach is a stable community of the identified gastropods in the intertidal zone. As a stable ecosystem, it means that the resources of the community can support its population, thus maintaining its carrying capacity.

\section{CONCLUSION}

Species of gastropods are abundant in the sandy and rocky intertidal zone of Asry Beach, Kingdom of Bahrain. Some species of the identified gastropods significantly vary in number within the taxonomic groups. The indices of diversity measure the heterogeneity, alpha diversity and species richness of the area. The intertidal zone serves as a stable habitat for marine gastropods.

\section{REFERENCES}

[1] W. Hamza and M. Munawar, Protecting and Managing the Arabian Gulf: Past, Present and Future, in Aquatic Ecosystems Health and Management, 2009, vol. 12, pp. 1-13.

[2] C. Aldea, C. Olabama and S. Troacoso, Bathymetric zonation and diversity gradient of gastropods and bivalves in West Antarctica from the South Sketland to the Bellingshausen, in Oceanic Research, 2008, paper 01/55:350-368.

[3] M. Gustavo, R.S. Cardoso and A.S. Dos Santos, Environmental effects on the structure of polychaete feeding guilds on the beaches of Sepeiba Bay, South-eastern Brazil, Journal of the Marine Biological Association of the United Kingdom, 2012.

[4] C. Elaiyaraja, R. Rajasekaran and V. Sekar, Checklist and occurrence of marine gastropods along Palkan Bay region, Southeast coast of India, Advances in Applied Science, 2013, 4(1):195-199.

[5] M. Schrodi, JM. Bohn, N. Brenke, E. Rolar and E. Schwake, Abundance, diversity and latitudinal gradients of Southeastern Atlantic and Antarctic abyssal gastropods, Deep Sea Research Part II: Tropical Studies in Oceanography, vol. 58, Issues 1-2, pp. 49-57, January 2011

[6] A.R. Kurhe, M.A. Rodriquez and G. DSuryawanshi, Vertical distribution and diversity of gastropods molluses from intertidal habitats of the Ratnagui Coast Maharashtra, India, International Research Journal of Natural and Applied Science, vol. 1, Issue 6, November 2014.

[7] P. Bouchet, P. Lozovet, P. Maestrati and V. Heros, Assessing the magnitude of species richness in tropical marine: exceptionally high numbers of molluscs at a New Caledonia Site, Biol. J. Linn Soc, vol. 75, No. 4, pp.421-436, 2002.

[8] K. Sakthivel and S. Antong Fernando, Gastropod diversity in Mudasal Odai and Nagapattinama Southeast coast of India, Indian Journal of Geo-Marine Sciences, vol. 43(4), Decemeber 2014.

[9] K. Analuddin, Nasarudin, W. Masa, W.O. Sarlytiana, and S. Rahin, Spatial trends in the community structure of gastropod assemblages, the coastal area of Tomia Island, Wakatobi Marine National Park, Indonesia, International Journal of Development Research,, vol. 3, Issue 11, pp.162-167, November 2013.

[10]E. RJ. Navarro, C.M. Villa and C.M. Uriate, Bivalves and gastropods of the Gulf of Tehuantepec, Mexico: A checklist of Species with Notes in their Habitat and Local Distribution, Journal of Marine Biology, pp. 1-13, vol. 2009.

[11]A.N. Joseph and K. I. Juliet, Comparative study of benthic macroinvertebratesin the eastern and western parts of Lagos Lagoon, Nigeria, Environmental Research Journal, vol. 4, Issue 2, pp. 182-186, 2010.

[12]M.H. Cassini, Ecological principles of species distribution model habitat matching rule, Journal of Biogeography, 38:2057-2065, 2011

[13]V.K. Wafarm, B. Ingole, A.S. Khan, and B.P. Loka, State of knowledge of coastal and marine biodiversity of Indian Ocean countries, PLOS ONE 6(1) ie 14613.doi: 10.1371 /journal .pone. 0014613 .

[14]I.V.Volvenko, The importance of species diversity and its components as criteria for selecting nature conservation areas, Russian Journal of Marine Biology, vol. 37, No. 7, pp. 604-607, 2011.

[15]M.G. Matias, A.J. Underwood and R.A. Colemar, Effects of structural diversity and identity of patches of habitat on diversity of 
benthic assemblages, Austral Ecology: Journal of Ecology in the Southern Hemisphere, 35,743-751, 2010.

[16] D.J. Currie, Disentangling the roles of environment and space in ecology, Journal of Biogeography, 34: 2009-2011.

[17]Marine animal division and adaptation to life in the seas and ocean, http://www.writework.com.easy/marine animal-diversity-andadaptation-life-seas-and-oceans, September 2014.

[18]A.J. Hamilton, Species diversity or biodiversity, Journal of Environmental Management, 89-92, 75(2009).

[[19] S. Smith and M. Rule, The effects of dredge-spoil dumping on a shallow water soft-sediment community in the Solitary Island Marine Park, NSW, Australia Marine Pollution Bulletin, vol. 42, pp. 104-108, 2011.

[20] M. Malaquias, D. Reid, T. Gosliner, and JL. Cerera, Diversity and speciation of marine gastropods, Phylogenetic Systematic and Evolution, 2009. 